concerned with the National Insurance Act. He put clearly and well the reasons why the doctors cannot and will not work under the Act as it stands at present; and the doctors will be glad that he reminded them of that delightful fable of the elephant and the partridge's nest.

At the Middlesex Hospital, Dr. Lazarus-Barlow chose a very different theme-the genius of the infinitely little. Why genius? Whatever attributes we may be able to assign in our imagination to the infinitely little, genius is not one of them. He ought to have said the kingdom, or the work, of the infinitely little. But he gave an admirable address. It was Pasteur, of course, of whom it was said that he had discovered the kingdom of the infinitely little. But, as Dr. Lazarus-Barlow told his audience, beyond the kingdom of the bacteria there is the kingdom of the radium emanations, which are infinitely littler; and beyond the kingdom of the radium emanations there is the kingdom of the enzymes, which are infinitely littlest. Not thought, but wonder alone, is possible in the presence of the facts of these kingdoms. It takes a very metaphysical mind to be near them.

With a sort of shock we come to Dr. Jane Walker's address to the London School of Medicine for Women. Her theme was common sense. It is a fertile subject for a medical address, and she treated it with delightful simplicity and directness. She began with those two prophets without honour in their own country, MacCormac of Belfast, and Boddington of Sutton Coldfield, who advocated the open-air treatment of consumption when as yet there was no clear understanding as to the cause and the nature of that disease. Next she praised, for the splendour of their common sense, St. Francis, Ambroise Paré, and Dr. Johnson. We think that St. Francis would rather be excused; and Dr. Johnson, like the doctors in the line "Who shall decide where doctors disagree?" was not a medical doctor; but Ambroise Paré is all right; his common sense is magnificent and unfailing. Dr. Walker gave many other pleasant and memorable examples of the sovereignty of common sense in the wisdom of life. It may be permitted to quote one out of many.

Take the case of the "mentally defective" problem. Are we not just a little lacking in common sense in our dealing with that? Surely our attention ought to be more earnestly directed to the so-called normal people, that they do not tempt their feebler brothers and sisters, who, left alone, would do them little harm. When one reads the flood of literature that is constantly being poured out about the "menace of the feeble-minded," one is tempted to feel that a good deal of it is mere nonsense.

Indeed, we hope that all the women students who heard Dr. Walker's lecture will follow her good advice; and it is a good thing for our lady doctors in this country that they have this keen eye for the importance of common sense in medical and surgical practice.

Dr. Humphrey Rolleston's address at ManNo. 224I, vol. 90] chester University is perhaps the best of all in regard to thoroughness and careful weighing of his words. He took for his subject "Universities and Medical Education." As a Cambridge man, who is likewise an examiner in Manchester University, he was able to speak with authority of the complex and ever-shifting relations between all that is called Literæ Humaniores, the medical sciences, and medical and surgical practice. It would be hard to beat his ideal of the first years of medical education.

The education best suited for a medical student before beginning his professional subjects should be on the following lines. The subjects ordinarily taught in schools, including Latin and Greek, should be pursued until the age of about $15^{\frac{1}{2}}$ years, when the student's proficiency should be tested by an examination, the results of which should count at the university matriculation. After passing this examination the student should spend the next $2-2 \frac{1}{2}$ years in obtaining a sound knowledge of French and German, literature, English composition, physics, and chemistry, and the necessary mathematics. At the end of this time, when he is from $17 \frac{1}{2}$ to 18 years of age, he should be able to pass an examination on these subjects, and then begin the study of biology and of anatomy and physiology. This compromise would ensure general culture with a modicum of classical training, and a knowledge of French and German at a time when it can be readily acquired, and yet would not encroach unduly on the time necessary for strictly professional instruction. This education, which is somewhat on the lines provided on the modern side, would be far better than that given on the classical side at public schools, and by providing a good basis of physics and chemistry would do much to remedy the prevailing difficulty of the early science examinations in the medical curriculum.

While introductory addresses remain as good as these four, it would certainly be a pity to desert this way of observing the opening of our medical schools.

\section{THE CHURCH CONGRESS AT MIDDLESBROUGH.}

D URING the week ending on Saturday, October 5, the Church Congress has been holding its annual gathering at Middlesbrough, the great industrial centre of population which has grown up at the mouth of the Tees. The choice of such a meeting-place is at once a declaration and a challenge-a declaration that the Church considers the problems of industrialism to be also the problems of religion, and a challenge to those people who would solve the riddles of capital and labour without reference to a spiritual basis for the aspirations of both parties in the conflict. It is well that any body of men and women joined together to discuss the outstanding difficulties of a common faith should feel able at times to dispense with the inspiration of mediæval architecture and academic hall and should go forth boldly to conduct their deliberations on the edge of a populous and rapidly depleting coal-field, illuminated with the glare of titanic blast furnaces.

On the whole, the choice of subjects and their treatment by the selected speakers has justified 
the action of the organising committee. We do not look to such meetings to produce any contribution to knowledge, but rather to express an attitude of mind and to set an example of a right method of approach to the vexed questions of the day. The eminently sane and statesmanlike influence of the Archbishop of York was felt throughout the proceedings, and his opening address contained an excellent summary of the ground to be traversed in these meetings of the Congress, and indicated the point of view from which he desired that it might be surveyed.

The papers and discussions on town planning and rural housing showed signs of a healthy realisation of the economic aspects of that question. Cottages never will and never ought to be built in any number and let at rents less than their true economic value. Such a course of action, from whatever motives it be adopted, leads in the end to a depreciation of wages. It is, in fact, a return by a circuitous route to the old and evil plan of a subsidy to wages through a widespread extension of a method of outdoor relief - a system which, under the old ante-I 834 Poor Law, proved to be pauperisation in one of the worst forms. Only when it is realised that, as Mr. Raymond Unwin declared was already the case, it pays to provide good housing accommodation and that garden villages are a better form of investment than potential slums shall we see the end of the long series of lamentable mistakes in housing, some of which have recently been perpetrated afresh in connection with the opening up of the new industrial areas at Doncaster and Dover.

The question of the falling birth-rate, a fall which is very marked in the manufacturing cities of the northern provinces, wherever women are employed in factories, was dealt with by $\mathrm{Mr}$. W. C. D. Whetham, F.R.S., who again emphasised the frequent opposition in present circumstances between the economic and the religious aspect of normal family life. The Church of England, unlike the Church of Rome, has not yet grasped the fact that the number and quality of her future members, indeed, her very corporate existence, can be made the plaything of social, industrial, and moral forces with which she has neglected to concern herself.

From the academic point of view, the most interesting morning was that devoted, on Thursday, to a discussion of the relation of miracles to the Christian faith, a contribution towards the agelong effort to reconcile intuitive belief and intellectual reason and to assign to each their true importance in the religious life. The subject was opened by the Dean of Christ Church (Dr. Strong) with an admirable attempt to determine how far, in the light of all knowledge at present available, it was practicable to answer the question: "Are miracles possible at all?" The Dean gave an excellent account of modern thought relating to the purely mechanical theory of life, which would regard the world as a closed system, controlled by unerring laws of matter and motion, and in which the appearance of a miracle could only be explained as the result of imperfect observation or incorrect deduction. But he pointed out that recent tendencies, both in philosophy and biology, would seem to lead away from and not towards the acceptance of such a mechanical view of nature as the complete and ultimate solution of the whole problem of existence and consciousness.

Prebendary Webb-Peploe's contribution, which was much applauded, served to remind us that for those people who are prepared to adopt intact into their theological belief the experiences attributed to Job, Daniel and Jonah, the efforts of learned professors and others to alleviate their lot are both officious and ill-judged. The discussion was closed by the Archbishop, who referred to some of the papers read at the recent meeting of the British Association for the Advancement of Science, held at Dundee, and concurred with the Dean that at the present moment it was the mechanical theory of the universe, quite as much as the miraculous basis of Christianity, that was on its trial in the world of thought. His Grace's closing sentences, as reported in The Times, may perhaps be given to sum up the general trend of the whole discussion. "The real meaning of the miraculous was that it was an assurance given to them that, ultimately, the Divine Being was free and master in His own house; and it was the coming forth of that fact into the world that carried with it the consequences that they called miracles."

\section{NOTES.}

THE meeting to be held at the Mansion House on October 23, in connection with the proposed memorial to the late Lord Lister, is the outcome of a movement which was set on foot by the presidents of the Royal Society and the Royal College of Surgeons. A large and influential committee has been formed, representative of scientific, medical, and general interests, both in this country and abroad, and the various possible schemes, including a memorial in Westminster Abbey, and others of an international character, will be laid before the meeting, which it is hoped will be largely attended.

The Royal Microscopical Society has arranged to hold a conversazione at King's College, London, on Wednesday, October I6, from 8 to II p.m.

THE extension to the Manchester Museum will be opened on the afternoon of Wednesday, October 30 , by $\mathrm{Mr}$. Jesse Haworth. An address will be delivered by Prof. W. M. Flinders, F.R.S.

Mr. E. Grant Hooper, superintending chemist, Government Laboratory, and vice-president of the Society of Chemical Industry, has been appointed Deputy-Government Chemist, in succession to $\mathrm{Mr}$. H. W. Davis, who has retired.

Sir George Darwin, K.C.B., F.R.S., Plumian professor of astronomy at Cambridge, who, wr regret to learn, has been ill for two or three weeks, underwent a severe operation on Thursday last. On Sunday he spent a bad night, but we are glad to be able to state that he is now making good progress. 